\title{
The bucket test reinterpreted: a study on benign paroxysmal positional vertigo and Ménière's disease patients
}

\author{
Angel Castro-Urquizo ${ }^{1} \mathbb{D}$, Erika Celis-Aguilar ${ }^{1 *}$ (D) and Guillermo Alejandro Rubio-Partida ${ }^{2}$ (D)
}

\begin{abstract}
Background: The bucket test is a simple and practical instrument to evaluate vestibular diseases; additionally, it could be a useful tool in the evaluation of the vertigo patient. Unfortunately, the bucket test still lacks standardization. The objective of this study was to evaluate and to interpret the subjective visual vertical (SW) using the bucket test in benign paroxysmal positional vertigo (BPPV) and Ménière's disease patients. We performed a cross-sectional study in a secondary care center. All patients with diagnosis of unilateral posterior canal BPPV or Ménière's disease underwent complete neuro-otological physical examination and the bucket test. Normal bucket test was $0^{\circ}$ to $3^{\circ}$ according to previous study.

Results: We included seventy-eight subjects. Benign paroxysmal positional vertigo cases $(n=51)$ showed a mean $2.62^{\circ}$ of SW prior to the Epley maneuver and $1.7^{\circ}$ of SW after the maneuver $(p=<0.001), 57 \%$ of patients with BPPV were categorized as abnormal. Inactive Ménière's disease patients $(n=22)$ had mean SW of $2.74^{\circ}$ and Ménière's disease with active crisis $(n=5)$ had $5.06^{\circ}$ of SW $(p=0.002)$.
\end{abstract}

Conclusion: The bucket test is a simple and useful test for the evaluation of SW, and it has a role in the evaluation of patients with active vestibular diseases such as Ménière's disease and BPPV.

Keywords: Bucket test, Vestibular diseases, Otolith, Ménière's disease, Benign paroxysmal positional vertigo

\section{Background}

An impairment of the subjective visual vertical (SVV) is one of the most sensitive signs of acute vestibular imbalance, due to central or peripheral disorders. Bucket test is a very simple and economical method to detect and evaluate the SVV, especially in patients with some vestibular disability [1].

The bucket test is easy and quick to perform; a previous study has defined a normal range of $0^{\circ}$ to $3.0^{\circ}$ in the healthy population [2]. In that study, normal values of SVV deviation were $1.4^{\circ} \pm 1.9^{\circ}$ with a range of $-0.5^{\circ}$ to

\footnotetext{
* Correspondence: erikacelis@hotmail.com

Part of this data was presented at the American Academy of Otolaryngology Meeting 2019 as a poster.

'Department of Otolaryngology, Civil Hospital of Culiacan, CIDOCS, Universidad Autónoma de Sinaloa, Eustaquio Buelna No. 91 Col. Gabriel Leyva, C.P, 80030 Culiacán, Sinaloa, México

Full list of author information is available at the end of the article
}

$3.3^{\circ}$ (with 2 standard deviations (SD)). Also, the mean measurements without including negative values were $1.61^{\circ} \pm 1.44^{\circ}$ with a range of $0.2^{\circ}$ to $3.1^{\circ}$ (with two standard deviations) [2]. The deletion of the negative values provided a more straightforward interpretation of the bucket test. Our current study is based on this normal values.

Few studies have evaluated the SVV in patients with vestibular disorders, therefore the results and the scales remain inconclusive [3]. The SVV depends on visual, vestibular and somatosensory signals. An acute lesion in the peripheral vestibular system may cause distortion of the subjective visual vertical toward the affected side. Thus, a person with vestibular diseases finds it difficult to perceive a vertical line and refers it to be deviated; this deviation can be measured in degrees [4].

\section{Springer Open}

(- The Author(s). 2021 Open Access This article is licensed under a Creative Commons Attribution 4.0 International License, which permits use, sharing, adaptation, distribution and reproduction in any medium or format, as long as you give appropriate credit to the original author(s) and the source, provide a link to the Creative Commons licence, and indicate if changes were made. The images or other third party material in this article are included in the article's Creative Commons licence, unless indicated otherwise in a credit line to the material. If material is not included in the article's Creative Commons licence and your intended use is not permitted by statutory regulation or exceeds the permitted use, you will need to obtain permission directly from the copyright holder. To view a copy of this licence, visit http://creativecommons.org/licenses/by/4.0/. 
There are other methods to evaluate the SVV, such as the hemispheric dome or the luminous bar in dark room, which are expensive, need a specific room, and need trained personnel. The above are disadvantages that might be overcome with the bucket test [5].

The pathophysiology in relation to the SVV and the affected side is not fully understood. Probably, in benign paroxysmal postural vertigo (BPPV) the reduction of the SVV values after the particle replacement maneuvers is due to the return of the debris to the utricle [6].

In the literature, there is controversy not only on the performance of the bucket test but also on the interpretation. There are also no clear results since the bucket in itself is made differently across studies as well as the protocol of application is diverse [2]. There is a lack of studies that compare the bucket test with the different vestibular pathologies. Furthermore, even fewer studies interpret their results based on their normal volunteer studies [2].

Our main objective is to evaluate and interpret the SVV measurements using the bucket test on multiple vestibular disorders (unilateral posterior canal BPPV and Ménière's disease) and to compare them to normal values, previously established on normal volunteer SVV results [2].

\section{Methods}

A cross-sectional study was performed in a secondary care center from January 2017 to March 2019.

\section{Subjects}

For the inclusion criteria, we included all subjects that were $\geq 18$ years with a diagnosis of unilateral canal BPPV or Ménière's disease. Exclusion criteria were patients with vertigo of central origin, other diagnosis of peripheral vertigo, patients with blindness, and patients who did not give their informed consent to participate in this research.

Otologic and neurological symptoms were collected, and neuro-otological examination was performed in all patients. Neurotologic examination included otoscopy, Snellen card, head impulse test, tuning fork tests, and cranial nerve examination. Also, complete neurologic examination was performed, with the evaluation of eye movements, cerebellar tests, gait, and Romberg. Dix hallpike was performed on all subjects.

Meniere's patients underwent audiometry, with bone and air conduction thresholds performed with an Interacoustic model, AD629 in a soundproof cabin. MRI was indicated in those cases with asymmetric hearing loss, in whom a retrocochlear lesion was discarded.

The diagnosis of peripheral vestibular disorder was established by the senior author.

\section{Diagnostic criteria of vestibular pathologies}

BPPV was diagnosed through the Dix Hallpike maneuver, based on the Clinical practice guideline: benign paroxysmal positional vertigo [7]. Positive unilateral rotatory nystagmus with a vertical component on the Dix Hallpike maneuver was a strict criteria for inclusion. Only unilateral posterior semicircular canal BPPV was included in this study.

All Ménière's disease patients underwent audiometry, finding sensorineural hearing loss of the affected side; only definitive Ménière's disease patients were included. The Equilibrium Committee amendment to the 1995 AAO-HNS guidelines were used for the definition of definitive Ménière's disease [8], and in these patients, vestibular migraine was discarded [9]. Active Ménière's disease was defined as vertigo occurring within 1 week of clinical examination.

\section{Bucket test technique}

The SVV was evaluated binocularly using the bucket test. An opaque plastic bucket was used, with a $25-\mathrm{cm}$ and $23-\mathrm{cm}$ diameter. Inscribed on the inside bottom of the bucket was a straight line. Inscribed on the outside was the same straight line, with a protractor and weighted plumb line to indicate degrees of rotation of the inscribed line from true vertical, which extended from $-40^{\circ}$ to $+40^{\circ}$. The internal vertical line corresponded perfectly to the line indicating $0^{\circ}$ on the angle protractor, the procedure has been previously published [2].

The subject sitting in a straight position, placed his face inside the bucket. Patients attempted to align a vertical line inscribed at the inside bottom of a bucket to the true vertical in the absence of external visual cues. The subject could not see beyond the rim of the bucket, providing no cues to visual orientation. To measure the SVV, the bucket was randomly rotated by the examiner, in the clockwise or counterclockwise directions. Each time, the patient received the bucket from the examiner and the patient rotated the bucket until the line reached the vertical position. Ten repetitions of the procedure were performed, five consecutive attempts in the clockwise and five consecutive attempts in the anticlockwise direction. The angular inclinations of the vertical position were measured in degrees. The evaluator recorded the degrees of deviation for each of the attempts made [2]. Only positive values were considered during statistical analysis.

Normal was defined as $0^{\circ}$ to $3^{\circ}$ according to previous value findings [2], since these are the normal values of our population.

All subjects signed informed consent. This study was approved by our institutional review board (number 290). 


\section{Time of performance of the bucket test}

Ménière's disease patients had one measurement at the time of their clinical appointment.

Unilateral posterior canal BPPV patients had two measurements in the same visit, one before the implementation of the Epley maneuver and the other immediately posterior to the particle repositioning maneuver (PRM).

Both SVV measurements performed on BPPV patients underwent the same procedure technique described previously.

\section{Outcome measurements}

- Mean and 2 standard deviations of the bucket test were measured, without considering negative values.

- Ipsilateral vs contralateral deviations of the bucket test, according to the side of the vestibular lesion

- Number and percentage of abnormality on the bucket test by pathology

In this manner, we explained all the possible outcomes with the use of the bucket test in vestibular disease patients.

\section{Statistical analysis}

The Statistical Program for Social Sciences (SPSS Inc. version 21, IBM, Chicago, IL, USA) was used for statistical analysis. A descriptive analysis was made using mean, median, standard deviation (SD and 2SD), and maximum and minimum values of clockwise and counterclockwise directions and the total attempts.

Categorical variables were described with frequencies and proportions. Continuous variables were compared with a $t$ test. Paired $t$ tests were used to compare clockwise and counterclockwise measurements of the same subjects. Independent sample $t$ test was obtained for inactive vs active Ménière's disease comparison. The range of SVV deviation mean \pm 2 standard deviations were calculated. $P<0.05$ was considered significant.

\section{Results}

Seventy-eight volunteers with vestibular disorders were included, 54 were women $(69.23 \%), 24$ were men (30.76\%) with a mean age of 53 years (range 22-81). See Table 1.

We included $n=51$ BPPV patients; bucket test measurements were performed before and after the PRM in all 51 patients. There were $n=27$ Ménière's disease patients, $n=22$ with inactive Ménière's disease and $n=5$ with active Ménière's disease.

Abnormal values were obtained in $54 \%$ of the total population-Ménière's and BPPV patients (Fig. 1).

Additionally, impaired values were obtained in $57 \%$ of the unilateral posterior canal BPPV subjects (Fig. 1).
Table 1 Baseline demographic data

\begin{tabular}{llll}
\hline Characteristic & Patients $(\boldsymbol{n}=\mathbf{7 8})$ & Frequency & $\mathbf{( \% )}$ \\
\hline Age (years) & Mean & 53 & \\
& Range & $22-81$ & \\
Sex & Women & 54 & 69.23 \\
& Men & 24 & 30.76 \\
Affected vestibular side & Right & 46 & 58.97 \\
& Left & 32 & 41.02 \\
Pathologies & BPPV & 51 & 65.38 \\
& Ménière's disease & 27 & 34.61 \\
\hline
\end{tabular}

$n$ sample size, BPPV benign paroxysmal positional vertigo

Results in BPPV patients were $2.62^{\circ} \pm 3.64^{\circ} 2 \mathrm{SD}$, ($1.02^{\circ}$ to $6.26^{\circ}$ ) before the Epley maneuver and $1.7^{\circ} \pm$ $2.92^{\circ} 2 \mathrm{SD},\left(-1.22^{\circ}\right.$ to $\left.4.62^{\circ}\right)$ after the Epley maneuver $(p$ $=<0.001)$. For more detailed results on BPPV patients, see Table 2 .

In patients with Ménière's disease $(n=27)$, the results were $2.74^{\circ} \pm 3.9^{\circ} 2 \mathrm{SD}\left(-1.16^{\circ}\right.$ to $\left.6.64^{\circ}\right)$. Inactive Ménière's disease patients $(n=22)$ had mean SVV of $2.74^{\circ}$ and Ménière's disease with active crisis $(n=5)$ had $5.06^{\circ}$ of SVV $(p=0.002)$. See Table 3 . Eighty percent of active Ménière's disease patients had abnormal values. See Fig. 1.

The deviation corresponded to the affected side in $80 \%(n=4)$ of active Ménière's disease (Fig. 2).

Clockwise and counterclockwise rotations of the bucket showed no statistical difference, both in BPPV and Ménière's disease ( $p=0.9, p=0.62$, respectively).

\section{Discussion}

Our SVV results in vestibular disease patients provide a better understanding of the bucket test in different vestibular pathologies.

The utricule and saccule provide the sense of verticality and therefore supply the information for the SVV [4]. Also, the SVV in vestibular disease patients generally deviates towards the affected side, making the bucket test a practical tool to measure subjective verticality [1].

Furthermore, the bucket test represents the opportunity to follow the function of the utricule and the otolith organs and thus, provide a useful follow-up on the recovery of the patient. It has been found that the recovery of SVV in a labyrinthectomy patient can be demonstrated weeks after surgery [4].

According to our demographic data, in this study, we observed more female patients in the sixth decade of life. The age of our patients was similar to that previously described by Cohen et al., Hong et al., and Von Brevern et al. [3, 10, 11]. Additionally, former literature has reported a predominance of female patients except for one study [12]. 


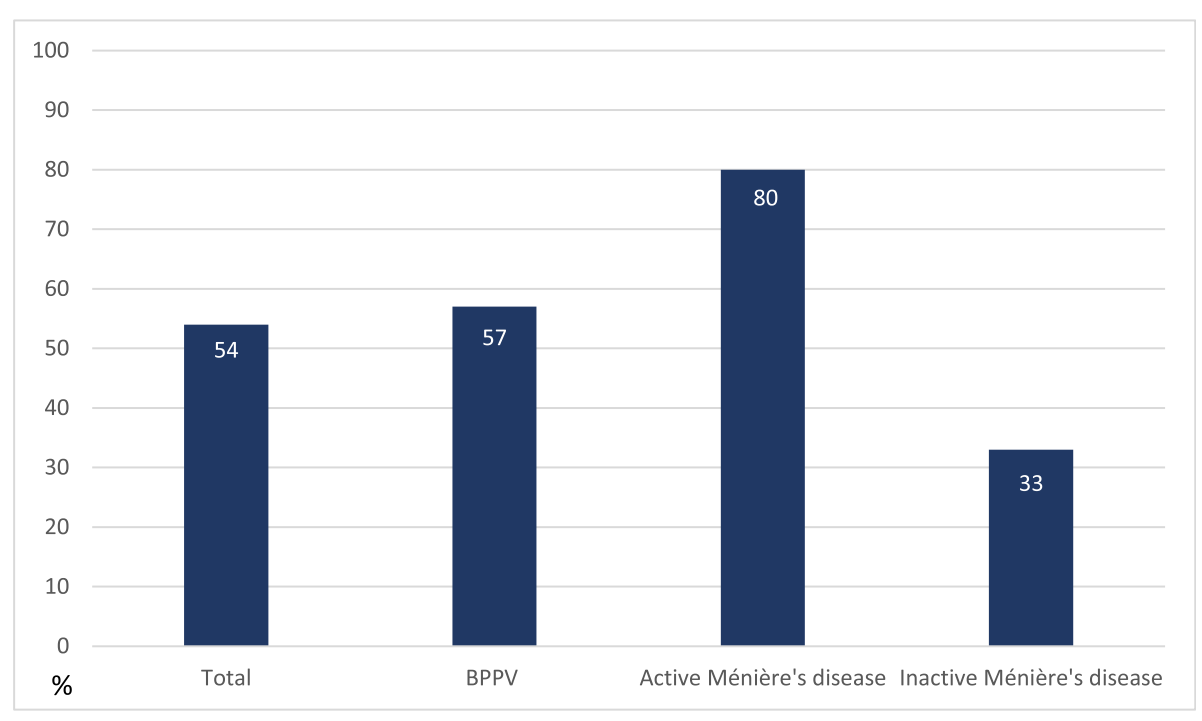

BPPV: benign paroxysmal positional vertigo

Fig. 1 Percentage of patients with abnormal values

In the present study, we analyzed patients with BPPV and Ménière's disease. Interestingly, vestibular neuritis patients were more common in other studies, probably due to the participation of emergency department patients [4, 12-14]. In contrast, our study was mainly undertaken in an outpatient clinic.

To fully describe the use of the bucket test in patients with vestibular disorders (BPPV and Ménière's disease), there were two additional descriptions included: the side of the bucket deviation and its classification as normal or abnormal. See Figs. 1 and 2. In this manner, outcome measurements were mean, median, standard deviation, side of deviation, and percentage of abnormality.

Unfortunately, there is no current consensus on the use of the bucket test since there are diverse techniques previously described. For example, studies varied on the vestibular disorders included, the protocols performed, or the interpretations of results. Furthermore, there is conflicting data on the normal deviation range. Previous studies have attempted to standardize the bucket test implementation [1-3]. In our study, we have performed a literature review on the use of the bucket test in vestibular disorders, similarities, and controversies are outlined [2]. See Table 4 [1-4, 6, 15-19].

In the study by Zwergal et al. the examiner manipulated the bucket test. Healthy subjects were evaluated finding a mean of $2.0^{\circ}$ as normal range. Unfortunately, they did not specify the affected vestibular side. The authors performed the measurement on both monocular and binocular vision. On this study, Bucket test showed higher values, probably because more patients with acute and severe vertigo crisis were included, some examples were vestibular neuritis, cerebral stem infarctions and neurectomies. The mean described was $8.3^{\circ} \pm 5.0^{\circ}\left(3.3^{\circ}\right.$ to $11.3^{\circ}$ ) for binocular vision, and $8.7^{\circ} \pm 5.0^{\circ}$ (3.7 to $11.7^{\circ}$ ) for monocular vision [1].

Cohen et al. conducted a study with the bucket test, in order to assess the SVV in vestibular disorders. They performed 3 measurements clockwise and 3 counterclockwise in patients with BPPV and with unilateral

Table 2 Mean measurements in clockwise and counterclockwise directions in BPPV, based on 1SD and 2SD

\begin{tabular}{|c|c|c|c|c|c|}
\hline & $\begin{array}{l}\text { Clockwise direction } \\
\text { Mean, SD (range) }\end{array}$ & $\begin{array}{l}\text { Counterclockwise direction } \\
\text { Mean, SD (range) }\end{array}$ & $\begin{array}{l}\text { Total } \\
\text { Mean, SD (range) }\end{array}$ & $\begin{array}{l}\text { Total } \\
\text { median }\end{array}$ & $p$ \\
\hline $\begin{array}{l}\text { BPPV: before } \mathrm{PRM}^{\mathrm{a}} \\
(n=51) \\
1 \mathrm{SD}\end{array}$ & $2.61^{\circ} \pm 1.84^{\circ} \mathrm{SD},\left(0.77^{\circ}\right.$ to $\left.4.45^{\circ}\right)$ & $2.63^{\circ} \pm 2.04^{\circ} \mathrm{SD},\left(0.59^{\circ}\right.$ to $\left.4.67^{\circ}\right)$ & $2.62^{\circ} \pm 1.82^{\circ} \mathrm{SD},\left(0.8^{\circ}\right.$ to $\left.4.44^{\circ}\right)$ & $2.4^{\circ}$ & \\
\hline $2 S D$ & $2.61^{\circ} \pm 3.68^{\circ} 2 \mathrm{SD},\left(-1.07^{\circ}\right.$ to $\left.6.29^{\circ}\right)$ & $2.63^{\circ} \pm 4.08^{\circ} 2 \mathrm{SD},\left(-1.45^{\circ}\right.$ to $\left.6.71^{\circ}\right)$ & $2.62^{\circ} \pm 3.64^{\circ} 2 S D,\left(-1.02^{\circ}\right.$ to $\left.6.26^{\circ}\right)$ & & \\
\hline $\begin{array}{l}\text { BPPV: after PRM }{ }^{a} \\
(n=51) \\
1 S D\end{array}$ & $1.7^{\circ} \pm 1.43^{\circ} \mathrm{SD},\left(0.27^{\circ}\right.$ to $\left.3.13^{\circ}\right)$ & $1.7^{\circ} \pm 1.64^{\circ} S D,\left(0.06^{\circ}\right.$ to $\left.3.34^{\circ}\right)$ & $1.7^{\circ} \pm 1.46^{\circ} \mathrm{SD},\left(0.24^{\circ}\right.$ to $\left.3.16^{\circ}\right)$ & $1.1^{\circ}$ & $<0.001$ \\
\hline $2 S D$ & $1.7^{\circ} \pm 2.86^{\circ} 2 \mathrm{SD},\left(-1.16^{\circ}\right.$ to $\left.4.56^{\circ}\right)$ & $1.7^{\circ} \pm 3.28^{\circ} 2 \mathrm{SD},\left(-1.58^{\circ}\right.$ to $\left.4.98^{\circ}\right)$ & $1.7^{\circ} \pm 2.92^{\circ} 2 \mathrm{SD},\left(-1.22^{\circ}\right.$ to $\left.4.62^{\circ}\right)$ & & \\
\hline
\end{tabular}

$S D$ standard deviation, ${ }^{\circ}$ geometric degree, BPPV benign paroxysmal positional vertigo

${ }^{\text {a }}$ PRM particle repositioning maneuvers 
Table 3 Mean measurements in clockwise and counterclockwise directions in Ménière's disease, based on 1SD and 2SD

\begin{tabular}{|c|c|c|c|c|c|}
\hline & $\begin{array}{l}\text { Clockwise direction } \\
\text { Mean, SD (range) }\end{array}$ & $\begin{array}{l}\text { Counterclockwise direction } \\
\text { Mean, SD (range) }\end{array}$ & $\begin{array}{l}\text { Total } \\
\text { Mean, SD (range) }\end{array}$ & $\begin{array}{l}\text { Total } \\
\text { median }\end{array}$ & $p$ \\
\hline $\begin{array}{l}\text { Total Ménière's disease }(n=27) \\
1 S D\end{array}$ & $\begin{array}{l}2.82^{\circ} \pm 2.04^{\circ} \mathrm{SD},\left(0.78^{\circ} \text { to }\right. \\
\left.4.86^{\circ}\right)\end{array}$ & $2.67^{\circ} \pm 2.17^{\circ} \mathrm{SD},\left(0.5^{\circ}\right.$ to $\left.4.84^{\circ}\right)$ & $\begin{array}{l}2.74^{\circ} \pm 1.95^{\circ} \mathrm{SD},\left(0.76^{\circ} \text { to }\right. \\
\left.4.69^{\circ}\right)\end{array}$ & $2.4^{\circ}$ & \\
\hline $2 S D$ & $\begin{array}{l}2.82^{\circ} \pm 4.08^{\circ} 2 S D,\left(-1.26^{\circ} \text { to }\right. \\
\left.6.9^{\circ}\right)\end{array}$ & $\begin{array}{l}2.67^{\circ} \pm 4.34^{\circ} 2 S D,\left(-1.67^{\circ} \text { to }\right. \\
\left.7.01^{\circ}\right)\end{array}$ & $\begin{array}{l}2.74^{\circ} \pm 3.9^{\circ} 2 \mathrm{SD},\left(-1.16^{\circ} \text { to }\right. \\
\left.6.64^{\circ}\right)\end{array}$ & & \\
\hline $\begin{array}{l}\text { Ménière's disease with active crisis } \\
(n=5)\end{array}$ & $\begin{array}{l}5.44^{\circ} \pm 5.36^{\circ} 2 S D,\left(0.08^{\circ} \text { to }\right. \\
\left.10.8^{\circ}\right)\end{array}$ & $4.68^{\circ} \pm 2.82^{\circ} 2 \mathrm{SD},\left(1.86^{\circ}\right.$ to $\left.7.5^{\circ}\right)$ & $\begin{array}{l}5.06^{\circ} \pm 4^{\circ} 2 S D,\left(-1.06^{\circ} \text { to }\right. \\
\left.9.06^{\circ}\right)\end{array}$ & $4.2^{\circ}$ & 0.002 \\
\hline $\begin{array}{l}\text { Ménière's disease inactive crisis } \\
(n=22)\end{array}$ & $\begin{array}{l}2.22^{\circ} \pm 2.68^{\circ} 2 S D,\left(-0.46^{\circ} \text { to }\right. \\
\left.4.9^{\circ}\right)\end{array}$ & $\begin{array}{l}2.21^{\circ} \pm 4.2^{\circ} 2 \mathrm{SD}\left(-1.99^{\circ} \text { to }\right. \\
\left.6.41^{\circ}\right)\end{array}$ & $\begin{array}{l}2.22^{\circ} \pm 1.55^{\circ} 2 S D,\left(0.67^{\circ} \text { to }\right. \\
\left.3.77^{\circ}\right)\end{array}$ & $1.5^{\circ}$ & \\
\hline
\end{tabular}

SD standard deviation, ${ }^{\circ}$ geometric degree

vestibular paresis. In this last study, the examiner manipulated the instrument. Unfortunately, they concluded the bucket test could not be used as a screening test for vestibular impaired individuals [3] due to poor performance of the ROC (receiver operating characteristic) curve.

A study by Chetana et al. evaluated patients with BPPV, Ménière's disease and vestibular neuritis. They performed baseline and 2-week and 1-month follow-up measurements. The normal range used was $0^{\circ} \pm 2.0^{\circ}$; they also reported if the deviated side was ipsilateral or contralateral to the vestibular disease. The abnormal values described were $100 \%$ of patients with labyrinthitis, $81 \%$ of patients with vestibular neuritis, $52 \%$ with Ménière's, and $71 \%$ of patients with BPPV (similar to our study). They also showed that SVV values could normalize with time. Unfortunately, mean values per disease were not described. The affected vestibular side corresponded to the deviated side in most patients [4].
In a study conducted by Sapountzi et al., forty patients with a diagnosis of BPPV were enrolled. The average SVV value was $5.75^{\circ}\left(1.11^{\circ} \mathrm{SD}\right)$ with a range of $4.46^{\circ}$ to $6.68^{\circ}$ before particle replacement maneuvers. After 1 week, values progressed to near-normal ranges $\left(0^{\circ} \pm 2^{\circ}\right)$ [6]. Accordingly, our current study shows a reduction on mean SVV values after the Epley maneuver $(p=<$ 0.001); this is depicted in Table 2.

It is important to emphasize that previous studies in normal subjects have used preset values $0 \pm 2[15,16]$; nonetheless, our study follows the finding published by CelisAguilar et al. [2] ( -1 to +3$)$. Additionally, in our study, we did not find statistically significant differences when comparing clockwise and counterclockwise measurements.

Furthermore, Ferreira et al. compared the results of the SVV before and after the otolithic replacement maneuvers in 20 patients with BPPV. The mean SVV was $2.8^{\circ} \pm 1.1^{\circ} \mathrm{SD}$ with a range of $\left(1.7^{\circ}\right.$ to $\left.3.9^{\circ}\right)$. Nine patients had abnormal values before the replacement maneuvers,



BPPV: benign paroxysmal positional vertigo

Fig. 2 Percentage of patients that corresponded to the deviation side of the bucket test and the vestibular pathology 
Table 4 Review of previous studies with the use of the "bucket test" in patients with vestibular pathologies and in healthy volunteers

\begin{tabular}{|c|c|c|c|c|c|c|c|}
\hline \multirow[b]{2}{*}{ Study } & \multicolumn{3}{|c|}{ Normal subjects } & \multicolumn{4}{|c|}{ Vestibular compromised subjects } \\
\hline & $n$ & $\begin{array}{l}\text { Normal } \\
\text { range }\end{array}$ & $\overline{\text { Condition }}$ & $n$ & $\begin{array}{l}\text { Deviation } \\
\text { range }\end{array}$ & Condition & Interpretation of values \\
\hline \multirow[t]{2}{*}{$\begin{array}{l}\text { Zwergal } \\
\text { et al. } \\
\text { (2009) [1] }\end{array}$} & 30 & $\begin{array}{l}\text { Binocular: } \\
0^{\circ} \pm 2.3^{\circ}\end{array}$ & $\begin{array}{l}\text { Normal } \\
\text { subjects }\end{array}$ & 30 & $\begin{array}{l}\text { Binocular: } 8.3^{\circ} \\
\pm 5.0^{\circ}\left(3.3^{\circ} \text { to }\right. \\
\left.11.3^{\circ}\right)\end{array}$ & $\begin{array}{l}\text { Peripheral or central } \\
\text { vestibular lesion }\end{array}$ & $\begin{array}{l}\text { The examiner rotates the bucket. } \\
\text { They used mean } \pm 2 \mathrm{SD} \text {. } \\
\text { Does not specify which side is positive or negative. }\end{array}$ \\
\hline & & $\begin{array}{l}\text { Monocular: } \\
0^{\circ} \pm 2.5^{\circ}\end{array}$ & & & $\begin{array}{l}\text { Monocular: } \\
8.7^{\circ} \pm 5.0^{\circ} \\
\left(3.7^{\circ} \text { to } 11.7^{\circ}\right)\end{array}$ & & \\
\hline \multirow[t]{2}{*}{$\begin{array}{l}\text { Cohen } \\
\text { et al. } \\
\text { (2012) [3] }\end{array}$} & 50 & $\begin{array}{l}1.2^{\circ}\left(0.75^{\circ}\right. \\
\left.\text { to } 3.2^{\circ}\right)^{a}\end{array}$ & $\begin{array}{l}\text { Normal } \\
\text { subjects }\end{array}$ & 25 & $\begin{array}{l}2.1^{\circ}\left(1.5^{\circ} \text { to }\right. \\
\left.6.0^{\circ}\right)^{\mathrm{a}}\end{array}$ & BPPV (posterior) & $\begin{array}{l}\text { The examiner moved the bucket. } \\
\text { Degrees were read off on the outside scale by the } \\
\text { examiner. } \\
\text { They used mean but do not use SD. }\end{array}$ \\
\hline & & & & 25 & $\begin{array}{l}2.1^{\circ}\left(1.7^{\circ} \text { to }\right. \\
\left.7.5^{\circ}\right)^{\mathrm{a}}\end{array}$ & $\begin{array}{l}\text { Unilateral vestibular } \\
\text { weakness }\end{array}$ & $\begin{array}{l}\text { Does not specify which side is positive or negative. } \\
\text { Compare the values of the normal side against the } \\
\text { abnormal side of the subject. }\end{array}$ \\
\hline $\begin{array}{l}\text { Sun et al. } \\
(2014)[15]\end{array}$ & 51 & $0^{\circ} \pm 2.0^{\circ} *$ & $\begin{array}{l}\text { Normal } \\
\text { older } \\
\text { adults }\end{array}$ & 0 & --- & & $\begin{array}{l}\text { The examiner rotated the bucket. } \\
\text { A clockwise rotation of the vertical from the perspective of } \\
\text { the subject was designated as a positive deviation. }\end{array}$ \\
\hline $\begin{array}{l}\text { Chetana } \\
\text { et al. } \\
\text { (2015) [4] }\end{array}$ & 0 & $0^{\circ} \pm 2.0^{\circ} *$ & $\begin{array}{l}\text { Normal } \\
\text { subjects }\end{array}$ & 100 & $\begin{array}{l}\text { Range: } 2.0^{\circ} \text { to } \\
7.0^{\circ} * *\end{array}$ & $\begin{array}{l}\text { Vestibular neuritis, } \\
\text { BPPV, Ménière's } \\
\text { disease, Labyrinthitis }\end{array}$ & $\begin{array}{l}\text { The subject holds the bucket. } \\
\text { The examiner rotated the bucket. } \\
\text { Compare the values of the normal side against the } \\
\text { abnormal side of the subject. } \\
\text { Do not specify mean values of each pathology } \\
\text { (Do not use negative values). }\end{array}$ \\
\hline \multirow[t]{2}{*}{$\begin{array}{l}\text { Ferreira } \\
\text { et al. } \\
(2015)[16]\end{array}$} & $\begin{array}{l}M \\
= \\
50\end{array}$ & $\begin{array}{l}2.00^{\circ} \pm \\
0.80^{\circ} \\
\left(1.2^{\circ} \text { to }\right. \\
\left.2.8^{\circ}\right)\end{array}$ & $\begin{array}{l}\text { Normal } \\
\text { subjects }\end{array}$ & & --- & & \multirow[t]{2}{*}{$\begin{array}{l}\text { The bucket was rotated by the examiner } \\
\text { The angular inclinations were measured in degrees and } \\
\text { defined as positive deviations in the clockwise and } \\
\text { negative in the anti-clockwise direction, in relation to the } \\
\text { volunteer. }\end{array}$} \\
\hline & $\begin{array}{l}W \\
= \\
50\end{array}$ & $\begin{array}{l}1.65^{\circ} \pm \\
0.63^{\circ} \\
\left(1.02^{\circ} \text { to }\right. \\
\left.2.28^{\circ}\right)\end{array}$ & & & & & \\
\hline $\begin{array}{l}\text { Celis et al. } \\
\text { (2017) [2] }\end{array}$ & 50 & $\begin{array}{l}1.4^{\circ} \pm 1.9^{\circ} \\
\left(-0.5^{\circ} \text { to }\right. \\
\left.3.3^{\circ}\right)\end{array}$ & $\begin{array}{l}\text { Normal } \\
\text { subjects }\end{array}$ & & --- & & $\begin{array}{l}\text { Degrees were read off on the outside scale by the } \\
\text { examiner. } \\
\text { To the right of the examiner is positive (Left of subject). }\end{array}$ \\
\hline $\begin{array}{l}\text { Oliva et al. } \\
\text { (2017) [17] }\end{array}$ & 43 & $\begin{array}{l}1.57^{\circ} \pm \\
1.17^{\circ} \\
\left(0.4^{\circ} \text { to }\right. \\
\left.2.74^{\circ}\right)\end{array}$ & $\begin{array}{l}\text { Normal } \\
\text { subjects }\end{array}$ & 32 & $\begin{array}{l}3.48^{\circ} \pm 1.73^{\circ} \\
\left(1.75^{\circ} \text { to } 5.23^{\circ}\right)\end{array}$ & $\begin{array}{l}\text { Peripheral vestibular } \\
\text { pathology }\end{array}$ & $\begin{array}{l}\text { Patients with abnormality in caloric tests. } \\
\text { Conventional bucket test was performed and compared } \\
\text { with computer interface. }\end{array}$ \\
\hline $\begin{array}{l}\text { Ferreira } \\
\text { et al. } \\
(2017)[18]\end{array}$ & & --- & & 20 & $\begin{array}{l}2.8^{\circ} \pm 1.1^{\circ} \\
\left(1.7^{\circ} \text { to } 3.9^{\circ}\right)\end{array}$ & BPPV & $\begin{array}{l}\text { The bucket was rotated by the examiner. } \\
\text { The bucket test was performed after the Epley maneuver } \\
\text { and the mean value was: } 1.6^{\circ} \text {. }\end{array}$ \\
\hline $\begin{array}{l}\text { Sapountzi } \\
\text { et al. } \\
(2017)[6]\end{array}$ & 0 & $0^{\circ} \pm 2.0^{\circ} *$ & $\begin{array}{l}\text { Control } \\
\text { group }\end{array}$ & 40 & $\begin{array}{l}5.57^{\circ} \pm 1.11^{\circ} \\
\left(4.46^{\circ} \text { to } 6.68^{\circ}\right)\end{array}$ & BPPV & $\begin{array}{l}\text { It does not specify who manipulates the bucket test. } \\
\text { They do not consider negative numbers (affected side). }\end{array}$ \\
\hline $\begin{array}{l}\text { Michelson } \\
\text { et al. } \\
\text { (2018) [19] }\end{array}$ & 15 & $\begin{array}{l}-0.86^{\circ} \pm \\
3.97^{\circ} \\
\left(-4.83^{\circ} \text { to }\right. \\
\left.3.11^{\circ}\right)\end{array}$ & $\begin{array}{l}\text { Normal } \\
\text { subjects }\end{array}$ & & --- & & $\begin{array}{l}\text { The bucket was rotated by the examiner. } \\
\text { Negative numbers refer to the patient's right. } \\
\text { The same patients underwent a virtual test resulting in - } \\
0.48^{\circ} \pm 2.51^{\circ} \text {. }\end{array}$ \\
\hline
\end{tabular}

* Preset value in the study as normal range. ${ }^{* *}$ The range implies $85 \%$ of all subjects with abnormal SVV

$S V V$, subjective visual vertical; $n$, subjects considered for the sample; $M$, men; $W$, women

$B P P V$ benign paroxysmal positional vertigo. ${ }^{a}$ Mean (range: from minimum to maximum values)

and after the replacement maneuvers, only 2 patients remained with abnormal parameters. Therefore, the authors highlighted the reduction of the SVV values were evidently improved after the particle replacement maneuvers in patients with BPPV [18].
Within the limitations of our study, we lack patients with other vestibular disorders such as vestibular migraine, vestibular neuritis, labyrinthitis, and central vestibulopathies, among other vestibular pathologies. These latter pathologies are usually characterized by more 
severe clinical outcomes in contrast to those included in the present study.

Another possible limitation of this study is the previous medication of some patients and the fact that some did not have an active vestibular disease at the time of the bucket test (inactive Ménière's disease). In addition, it would have been interesting to observe the SVV parameters in a follow-up visit. It is highly likely that a significant reduction in the mean SVV could be a possible scenario.

Also, it would have been useful to compare other methods of measuring the SVV, such as the light bar test or the dome test with the results obtained in this study.

One of the strengths of this study was the sample size, previous studies have included fewer patients. We have also identified the SVV before and after particle reposition maneuvers in patients with BPPV. Additionally, we included two vestibular disorders such as BPPV and Ménière's disease.

We recommend considering the standard deviations (SD) to interpret the results, in addition to the mean SVV, as summoned by Zwergal and other studies [1,2]. In our study, we preferred to use 2SD to be comparable with previous studies [1]. Only positive values were considered in this study for a more straightforward presentation of data.

Also, the diagnosis of vestibular disorders in this study have followed the international guidelines and standard committees on the diagnosis of vestibular diseases.

According to our results, the SVV evaluation of Ménière's disease is helpful since $80 \%$ of patients with active Ménière's disease have abnormal SVV and it corresponded to the ipsilateral side.

Mean SVV values of Ménière's disease reached statistical significance when we compared the active form of the disease vs the inactive form. Also, BPPV values were different before and after the Epley maneuver. We need to remember this test is currently being tested for its effectivity by the medical community. This study adds on the information that can help us decide whether to use the Bucket test or not.

More studies are needed to corroborate our results and subsequently apply this diagnostic technique to these and other vestibular pathologies.

The bucket test represents an opportunity to measure the otolith organs on various vestibular diseases, and to localize and understand if there is otolith damage in our patient. Also, it could be a valuable tool in the future to measure rehabilitation, thus the importance to understand this valuable technique.

\section{Conclusion}

The bucket test is a simple and useful test for the evaluation of SVV, and it has a role in the evaluation of patients with active vestibular diseases such as Ménière's disease and BPPV.

\section{Abbreviations \\ AAOHNS: American Academy of Otolaryngology Head and Neck Surgery; BPPV: Benign paroxysmal positional vertigo; SD: Standard deviations; SW: Subjective visual vertical}

\section{Acknowledgements}

We would like to thank the Department of Otolaryngology and the Autonomous University of Sinaloa.

\section{Authors' contributions}

ECA: (1) substantial contributions to conception and design, acquisition of data, or analysis and interpretation of data; (2) drafting the article or revising it critically for important intellectual content; (3) final approval of the version to be published; and (4) agreement to be accountable for all aspects of the work in ensuring that questions related to the accuracy or integrity of any part of the work are appropriately investigated and resolved. ACU: (1) substantial contributions to conception and design, acquisition of data, or analysis and interpretation of data; (2) drafting the article or revising it critically for important intellectual content; (3) final approval of the version to be published; and (4) agreement to be accountable for all aspects of the work in ensuring that questions related to the accuracy or integrity of any part of the work are appropriately investigated and resolved. GARP: (1) substantial contributions acquisition of data and data analysis; (2) revising the article critically for important intellectual content; (3) final approval of the version to be published; and (4) agreement to be accountable for all aspects of the work in ensuring that questions related to the accuracy or integrity of any part of the work are appropriately investigated and resolved. The authors have read and approved the final manuscript.

\section{Funding}

There is no funding to declare.

Availability of data and materials

All data are original and do not infringe any copyright. The datasets used and/or analyzed during the current study are available from the corresponding author on reasonable request.

\section{Declarations}

Ethics approval and consent to participate

Ethical approval was obtained by our institution: Centro de Investigación y Docencia en Ciencias de la Salud, University: Universidad Autónoma de Sinaloa. IRB number is No. 290. All patients signed an informed consent; all patients signed a written informed consent.

\section{Consent for publication}

NA

Competing interests

The authors declare that they have no conflicts of interest.

\section{Author details}

${ }^{1}$ Department of Otolaryngology, Civil Hospital of Culiacan, CIDOCS, Universidad Autónoma de Sinaloa, Eustaquio Buelna No. 91 Col. Gabriel Leyva, C.P, 80030 Culiacán, Sinaloa, México. ²Faculty of Medicine, Universidad Autónoma de Sinaloa, Culiacán, Sinaloa, México.

Received: 12 December 2020 Accepted: 21 April 2021

Published online: 20 May 2021

\section{References}

1. Zwergal A, Rettinger N, Frenzel C, Dieterich M, Brandt T, Strupp M (2009) A bucket of static vestibular function. Neurology. 72(19):1689-1692. https:// doi.org/10.1212/WNL.0b013e3181a55ecf

2. Celis E, Castro A, Mariscal J (2018) Evaluation of the bucket test in healthy individuals. Acta Otolaryngol. 138(5):458-462. https://doi.org/10.1080/000164 89.2017.1410289 
3. Cohen H, Sangi-Haghpeykar H (2012) Subjective visual vertical in vestibular disorders measured with the bucket test. Acta Otolaryngol. 132:850-854. https://doi.org/10.3109/00016489.2012.668710

4. Chetana N, Jayesh R (2015) Subjective visual vertical in various vestibular disorders by using a simple bucket test. Indian J Otolaryngol Head Neck Surg. 67(2):180-184. https://doi.org/10.1007/s12070-014-0760-0

5. Eghlimi B, Schaaf H, Hesse G (2012) Measuring the subjective visual vertical using a portable system. HNO. 60(4):330-336. https://doi.org/10.1007/s001 06-011-2419-4

6. Sapountzi Z, Vital V, Psillas G (2017) Subjective visual vertical in patients with benign positional paroxysmal vertigo. Hippokratia 21:159 https://www.ncbi. nlm.nih.gov/pmc/articles/PMC6248000/. Accessed 1 Jan 2019

7. Bhattacharyya N, Baugh RF, Orvidas L, Barrs D, Bronston L, Cass S, Chalian AA, Desmond AL, Earll JM, Fife TD, Fuller DC, Judge JO, Mann NR, Rosenfeld RM, Schuring LT, Steiner RWP, Whitney SL, Haidari J (2008) Clinical practice guideline: benign paroxysmal positional vertigo. Otolaryngol Head Neck Surg. 139(5_suppl):47-81. https://doi.org/10.1016/j.otohns.2008.08.022

8. Goebel JA (2016) 2015 Equilibrium Committee Amendment to the 1995 AAO-HNS guidelines for the definition of Meniere's disease. Otolaryngol Head Neck Surg. 154(3):403-404. https://doi.org/10.1177/0194599816628524

9. Lempert T, Olesen J, Furman J, Waterston J, Seemungal B, Carey J, Bisdorff A, Versino M, Evers S, Newman-Toker D (2013) Vestibular migraine: diagnostic criteria. Consensus document of the Barany Society and the International headache society. Nervenarzt. 170(4):401-406. https://doi.org/1 0.1007/s00115-013-3768-x

10. Hong S, Park M, Cha C, Park CH, Lee JH (2008) Subjective visual vertical during eccentric rotation in patients with benign paroxysmal positional vertigo. Otol Neurotol. 29(8):1167-1170. https://doi.org/10.1097/MAO.0b013 e31818a0f3c

11. Von Brevern M, Schmidt T, Schonfeld U, Lempert T, Clarke AH (2006) Utricular dysfunction in patients with benign paroxysmal positional vertigo. Otol Neurotol. 27(1):92-96. https://doi.org/10.1097/01.mao.0000187238. $56583.9 \mathrm{~b}$

12. Min K, Ha J, Kim M, Cho CH, Cha HE, Lee JH (2007) Clinical use of subjective visual horizontal and vertical in patients of unilateral vestibular neuritis. Otol Neurotol. 28(4):520-525. https://doi.org/10.1097/01.mao.0000271674.41307.f2

13. Byun J, Hong S, Yeo S, Kim SH, Kim SW, Park MS (2010) Role of subjective visual vertical test during eccentric rotation in the recovery phase of vestibular neuritis. Auris Nasus Larynx. 37(5):565-569. https://doi.org/10.101 6/j.anl.2010.02.004

14. Brodsky J, Cusick B, Kenna M, Zhou G (2015) Subjective visual vertical testing in children and adolescents. Laryngoscope. 126(3):727-731. https:// doi.org/10.1002/lary.25389

15. Sun D, Zuniga M, Davalos M, Davalos-Bichara M, Carey JP, Agrawal Y (2014) Evaluation of a bedside test of utricular function in older individuals. Acta Otolaryngol. 134(4):382-389. https://doi.org/10.3109/00016489.2013.867456

16. Ferreira M, Cunha F, Ganança C, Ganança MM, Caovilla HH (2015) Subjective visual vertical with the bucket method in Brazilian healthy individuals. Braz J Otorhinolaryngol. 82(4):442-446. https://doi.org/10.1016/j.bjorl.2015.08.027

17. Oliva C, Ochoa N, Kuroiwa M, Barraza C, Núñez M, Breinbauer H (2017) New method to evaluate the vertical subjective test. Rev Med Chil 77:124-134 https://scielo.conicyt.cl/pdf/orl/v77n2/art02.pdf Accessed 2 Feb 2019

18. Ferreira M, Ganança M, Caovilla H (2017) Subjective visual vertical after treatment of benign paroxysmal positional vertigo. Braz J Otorhinolaryngol. 83(6):659-664. https://doi.org/10.1016/j.bjorl.2016.08.014

19. Michelson P, McCaslin D, Jacobson G, Petrak M, English L, Hatton K (2018) Assessment of subjective visual vertical (SW) using the "Bucket Test" and the virtual SW system. Am J Audiol. 27(3):249-259. https://doi.org/10.1044/2 018_AJA-17-0019

\section{Publisher's Note}

Springer Nature remains neutral with regard to jurisdictional claims in published maps and institutional affiliations.

\section{Submit your manuscript to a SpringerOpen ${ }^{\circ}$ journal and benefit from:}

- Convenient online submission

- Rigorous peer review

- Open access: articles freely available online

High visibility within the field

- Retaining the copyright to your article

Submit your next manuscript at $\boldsymbol{\nabla}$ springeropen.com 